\title{
最近の歯学
}

\section{4. 口腔外科}

\section{骨誘導能を有する人工骨の開発}

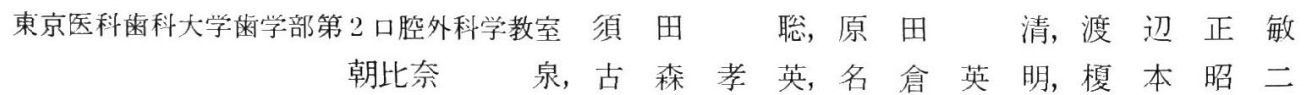

口腔外科ならびに顎顔面外科領域では, 顎骨に関連し た疾患が多く，久損した顎骨を補填あるいは再建するこ とが重要な課題の1つとなっている。その修復方法とし ては, 従来より新鮮自家骨移植が最良の方法であるとさ れ，現在に至るも頻用されている。自家骨移植では，移 植骨中に存在する bone morphogenetic protein (BMP) に より移植母床に存在する間葉系細胞が軟骨や骨に分化し ていくいわゆる骨誘導 (bone induction) の過程と, 移植 母床から新生した毛細血管や骨形成細胞が移植骨に侵入 して增殖するいわゆる骨伝導(bone conduction)の過程と が入り交り, 形成された新生骨に上り移植骨は移植母快 と結合する。しかしながら，自家骨移植には，採取量に 限度があり，また 2 次的な外科的侵襲を伴ら次点などが ある。一方，ハイトロキシフハタイトで代表される人工 生体材料は生体親和性も高く，使用が容易であるなどの 利点はあるが、移植母床に積極的に作用して骨新生を起 こさせるといら骨誘導能はない。

そこで，最近われわれの教室では，すでにUristや Reddi が報告した骨基質や象牙質基質中に存在する骨形 成因子 (BMP) に着目し，この蛋白をハイドロキンアパ タイトなどの生体忉料に涯加することにより，骨伝導能 上同時に骨誘導能を有する人工骨を開発するために種々 の実験を行ってきた。すなわち，Reddiらの方法に準じ て, ラット長管骨を䚈酸脱灰後, 塩酸グアニシンン可溶性 画分（BMP を含む画分）と不溶性画分（コラーゲン主 体の画分）とに分けて，これらをアパタイトに添加し移 植を行うと, アパタイト単独移植に比一, 骨形成蛋白と アパタイトの 2 者混合移植, あるいはそれにさらに不溶 性画分をも添加した 3 者混合移植の方が骨形成が著明に 起こることがわかった。骨形成蛋白の活性を十分発揮さ せるためには、コラーゲンを添加することが有效である が, nativeなコラーゲンでは今後の臨床応用を考光る場 合, 抗原性の点で問題があると考えられる。そこで, 仔 牛真皮コラーゲンから無菌的にしかる高純度に精製され
たアテロコラーゲン（高研製医療用ュラーダン）が抗原 性のきわめて少ない物質で，体内インプラントにも適し ていることを利用して，この医療用コラーダンゲルを添 加して動物実験を行ってみると，アパタイト・BMP・ 医療用コラーゲン 3 老混合移植でも骨形成が促進された (図 1)。

以上のことから，骨质導能と同時に骨誘導能をも有す る人工骨の開発が可能ではないかと考完, 現在, 牛骨拉 よびヒト象牙質から得られた骨形成蛋白を用いて動物実 験を積み重㸚ている。

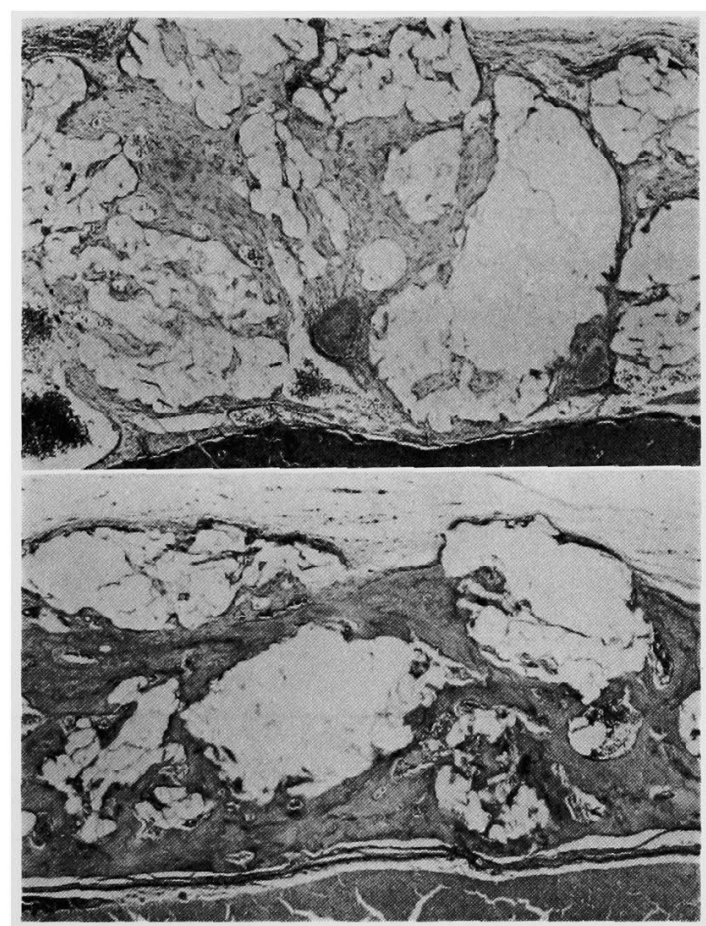

図 1 上は, 頭蓋骨欠損部へのアパタイト単独移植 (移植後 6 週)，下は，アバタイト・BMP・医療 用コラーゲン 3 者混合移植（移植後 4 週）の組 織像 